\title{
Abundance and Distribution of Bacterioplankton in the Gambia River, West Africa
}

\author{
Marcus J. Healey, Russell A. Moll, and Cheikh O. Diallo \\ Great Lakes Research Division, The University of Michigan, Ann Arbor, Michigan 48109, USA
}

\begin{abstract}
Four ecological zones of the Gambia River were sampled during four different hydrologic seasons for determination of microbial, nutrient, and physical parameters. A Greco-Latin Square experimental design was used to define the particular transect, station, depth, and tide/time-of-day of samples taken. Ranges of total bacterioplankton densities $\left(10^{6} \mathrm{cells} / \mathrm{ml}\right)$ were similar to those of tropical and temperate environments. Numbers of free bacteria were similar temporally, whereas attached bacteria numbers were greater during periods of high stream flows when suspended solids concentrations were higher. Free bacteria were usually twice as numerous in the freshwater zones than in the estuarine zones. Attached bacterial densities were approximately four times greater in the estuarine zones than in the freshwater zones. Uptake of ${ }^{3} \mathrm{H}$-glucose on both a sample volume and per-cell basis increased from the early stages of the flood $(6.95 \pm \mathrm{SE}$ $1.37 \mathrm{ng} /$ liter/hour and $3.8 \mathrm{pg} / \mathrm{hour} / 10^{6}$ cells, respectively) and reached observed annual maximums during the dry season $(21.01 \pm \mathrm{SE} 3.05 \mathrm{ng} /$ liter/hour and $13.0 \mathrm{pg} /$ hour $/ 10^{6}$ cells, respectively). Spatially, ${ }^{3} \mathrm{H}$-glucose uptake per sample volume and per cell was highest in the upper river zone and lowest in the lower estuary zone. The lower estuary zone consistently acted out of concert with the other river zones in terms of ${ }^{3} \mathrm{H}$-glucose and ${ }^{14} \mathrm{C}$-bicarbonate uptake. Analysis of variance (ANOVA) indicated that free and attached bacterioplankton densities were not homogeneous among transects, stations, depths, and tide/time-of-day at the different zones during the four hydrologic seasons. The results suggested that heterotrophy overshadowed autotrophy in the river and that the bacterial abundance, distribution, and glucose uptake activity in this tropical floodplain river were greatly influenced by the annual flood and the presence of extensive mangrove forests in the estuary.
\end{abstract}

\section{Introduction}

Native aquatic bacteria have traditionally been regarded as remineralizers of particulate organic matter (POM), efficient assimilators of low leveis of dissolved organics, and possible contributors of essential growth factors to organisms on other trophic levels [7, 11]. Studies by Williams [20] and Nixon [11] have indicated that the utilization of dissolved organic matter (DOM) from 
excretion by primary producers, from incomplete ingestion of cells by zooplankters, and from zooplankton fecal material is a primary role of heterotrophic bacterioplankton.

Much of the recent emphasis on bacterioplankton research has been on the determination of kinetic constants, bacterial production rates, and the quantification of biomass partitioning between different trophic levels. Most of the work published to date on bacterioplankton abundance and distribution has been performed in the estuaries and coastal waters of Europe and North America $[3,12,24]$. Few studies $[8,14,18]$ have investigated bacterioplankton in tropical environments, and fewer yet document bacterioplankton abundance and distribution over the course of 1 year from the headwaters to the mouth of a river.

Principal objectives of this study included an investigation of the spatial and temporal distribution of free and attached bacteria and bacterial metabolism $\left({ }^{3} \mathrm{H}\right.$-glucose uptake). As part of a larger effort to elucidate the ecological structure of the Gambia River, relationships among physical, chemical, and biological variables were examined to determine the relative importance of heterotrophs and autotrophs and the possible dependence of higher trophic levels on bacterial biomass.

\section{Methods}

The Gambia River Basin, which covers $77,100 \mathrm{~km}^{2}$, is a semitropical region located between 11 and $16^{\circ}$ west longitude. The basin has three distinct geographic regions: a hilly upper watershed in Guinea, a rolling continental basin in Senegal, and the eastern half of The Gambia and a very flat coastal plain in the western half of The Gambia. Figure 1 shows the locations of the study sites: lower estuary (Dog Island), upper estuary (Bia Tenda), lower river (Bansang), and upper river (Kedougou). Additional areas sampled on an intermittent basis were in the headwaters region and a small mangrove-lined, tidal creek, or "bolon," in the upper estuary.

Major factors considered in the sampling scheme were spatial heterogeneity and temporal variation. By using a Greco-Latin Square experimental design, spatial heterogeneity was addressed by taking samples at four study sites, at different transects within each site to assess longitudinal variation, at different stations on each transect to assess latitudinal variation, and at different depths at each station to assess vertical variation. Long-term temporal variation was addressed by collecting samples at four different times of the year corresponding to rising (July), flood (October), declining (December), and low (March) water. Short-term temporal variation was addressed by sampling at different times of the day and at different phases of the tide.

Four samples for plankton were collected during each of the four tide/time-of-day periods (day flood, night flood, day ebb, and night ebb) in each zone. This yielded an overall sampling design with 4 zones $\times 16$ samples $\times 4$ seasons $=256$ samples for each plankton component. Samples for physical and chemical analyses were collected in replicate at the same time as the bacterioplankton samples. The physical-chemical analyses included temperature, $\mathrm{pH}$, alkalinity, dissolved oxygen, total phosphorus, soluble reactive phosphorus, total nitrogen, nitrate-nitrogen, silica, chlorophyll $a$, and phaeopigments. Samples for glucose uptake and primary productivity were taken at the same time and location as the biological and chemical samples, but not with the same frequency.

The Greco-Latin Square sampling scheme defined the particular transect, station, depth, timeof-day, and tide of samples taken. Use of this sampling design permitted testing of seven hypotheses concerning the statistical differences in each variable, as determined by ANOVA, among zones, among transects within a zone, among stations within a zone, among different depths, between night and day, between ebb and flood tide, and between seasons. A required statistical assumption 


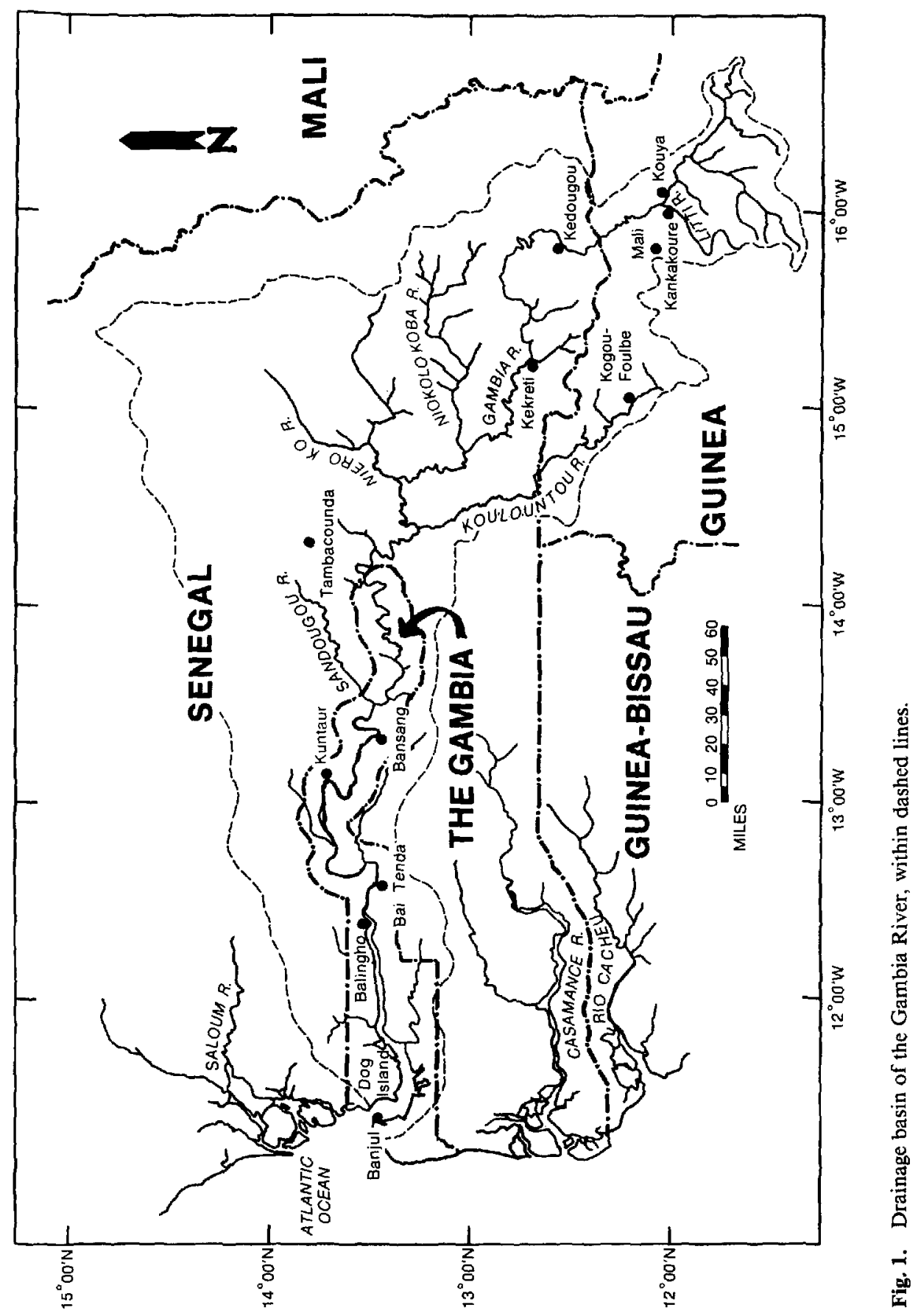


was that there was no interaction among any of the main blocking variables, i.e., transect, station, depth, and time-of-day $[10,21]$. ANOVA analyses were not used for the primary productivity and heterotrophic uptake studies.

All samples were collected with either a Kemmerer or Niskin bottle. Bacterioplankton samples were stored in $25 \mathrm{ml}$ plastic vials and fixed with two drops of $50 \%$ glutaraldehyde before refrigeration. An acridine orange direct count (AODC) method was used to enumerate the bacterioplankton by epifluorescence microscopy [7]. This technique, which is widely used for counting bacteria, provides highly reproducible estimates of bacterial abundance. However, estimates of attached bacteria suffer from problems associated with the differentiation and enumeration of free and particle-bound bacteria. Shear forces created by filtration remove loosely bound bacteria, and the particles themselves obscure both free and attached bacteria. For each sample, count/ml, percentage composition, mean, and standard deviation for both free and attached bacteria were calculated.

Suspended solids were determined gravimetrically after filtration through GF/C filters. Salinity and conductivity were measured using a YSI model 33 Conductivity-Salinity-Temperature meter (Fisher Scientific, Springfield, New Jersey). Temperature was measured with either the probe attached to the YSI meter or an expanded scale glass thermometer. An Orion model $501 \mathrm{pH}$ meter was used for the $\mathrm{pH}$ measurements (Fisher Scientific). Alkalinity was determined by titration. Samples for total and soluble nutrients were analyzed with a Technicon Autoanalyzer (Technicon Instruments Corp., Tarrytown, New York). Persulfate digestion techniques were employed in the determination of total nitrogen [4] and total phosphorus [9]. Chlorophyll $a$ and phaeopigments were determined after sample filtration through a $\mathrm{GF} / \mathrm{C}$ filter followed by maceration and extraction in a $90 \%$ acetone-water mixture. Chlorophyll concentrations were determined fluorometrically with a Turner Designs model 10 Fluorometer (Turner Designs, Mountain View, California). Concentrations of chlorophyll $a$ and phaeopigments were determined by the equations of Strickland and Parsons [15].

Uptake of ${ }^{3} \mathrm{H}$-glucose was considered an indication of the metabolic activity of the bacterial community. Inherent errors associated with the use of glucose as a measure of bacterial activity are that (1) some marine bacteria cannot use glucose and (2) glucose is poorly adsorbed to surfaces such as particles. These problems may serve to give a biased view of the metabolic activity of the bacterioplankton community. Glucose was used despite these weaknesses because of the predominantly freshwater character of the river in the upper river, lower river, and upper estuary zones. The method used in this study was based on the principle of adding a trace amount of carrier-free radioactive glucose to natural bacterial populations and measuring the rate at which the glucose is consumed by that population [2]. Uptake rates were interpreted as gross uptake of the added substrate $[6,23]$.

The experimental procedure was as follows. A sample of river water was collected with either a 5-liter Niskin bottle or a 3.5-liter Kemmerer bottle. Fifteen milliliters of sample was immediately placed into a sterile $25-\mathrm{ml}$ screw-top test tube. The test tube was sterilized in an autoclave at approximately 2 atmospheres pressure and $127^{\circ} \mathrm{C}\left(260^{\circ} \mathrm{F}\right)$ for $20 \mathrm{~min}$. Sterile tubes were kept tightly stoppered until used in the field. Sample water was placed into the tubes with a $5-\mathrm{ml}$ macro-pipette (three 5-ml injections). Incubations were conducted in triplicate for each water sample. Usually from three to six water samples were collected from each sampling location, with each sample from a different depth. Two to four sets of incubations were conducted during each field trip in each zone for a total of 6-24 incubations conducted in triplicate.

Each test tube with $15 \mathrm{ml}$ of sample was injected with $2 \mu \mathrm{Ci}$ of ${ }^{3} \mathrm{H}$-glucose (New England Nuclear, NET-1000, Boston, Massachusetts) as soon as all the incubation test tubes were filled. The glucose had a specific activity of $30 \mathrm{Ci} / \mathrm{mmol}$ and was carrier free. The weight of the injected glucose was $12 \mathrm{mg}$ which when diluted in $15 \mathrm{ml}$ of sample yielded a final concentration of $4.44 \mathrm{nM}$. Injection of the radionuclide was conducted in subdued light, and the samples were incubated in the dark at a temperature within $2^{\circ} \mathrm{C}$ of the original water temperature. The $2 \mu \mathrm{Ci}$ of radioactive glucose was contained in $0.2 \mathrm{ml}$ of sterile water which was slightly acidic, with an approximate $\mathrm{pH}$ of 4.0 . The glucose was prepared from sterile stock purchased in the United States and diluted to the correct working concentration. Five milliliters of glucose solution was sealed into glass ampules and autoclaved before shipment to Africa. One $5-\mathrm{ml}$ ampule was opened immediately prior to 
each set of incubations and the unused portion was discarded. Extreme care was taken not to contaminate samples in the tropical environment, which had an abundance of aerosol bacteria.

Samples were incubated for 2 hours, after which they were immediately filtered through a 4.5 $\mathrm{cm}$ diameter filter (Gelman Metricel) with a pore size of $0.2 \mu \mathrm{m}$. Samples were filtered with the aid of a slight vacuum (about one-half atmos.). Damp filters were removed from the filtering apparatus and placed in a scintillation vial containing $10 \mathrm{ml}$ of a water-dispersing scintillation cocktail (Amersham, ACS, Arlington Heights, Illinois). Vials were assayed for radioactivity on a Phillips Scintillation Counter at the Centre des Recherches Oceanographiques de Dakar-Thiaroye. Uptake of glucose was calculated using an external standard and corrected for quench and timezero uptake by the following formula:

$$
\underset{\mathrm{ng} / \text { liter } / \text { hour }}{\text { Uptake in }}=\frac{\text { [cpm uptake }- \text { time zero uptake }]}{[\mathrm{cpm} \text { added } \times \text { time of incubation }]} \times \underset{\text { ratio }}{\text { quench }} \times 800
$$

where the factor 800 is used to convert the concentration of glucose in the test tube $(4.44 \mathrm{nM})$ to weight in ng of glucose.

Primary productivity was estimated using the ${ }^{14} \mathrm{C}$-uptake method [5]. The following basic procedure followed standard techniques for the in situ incubation of phytoplankton. Stocks ${ }^{2}{ }^{14} \mathrm{C}$ bicarbonate (New England Nuclear, NEC-086H) were purchased in the United States and diluted to working strength with a slightly basic ( $\mathrm{pH} 8.0$ ) solution of distilled-deionized water. The $\mathrm{pH}$ of this solution was adjusted using trace amounts of carbonate and $0.01 \mathrm{~N} \mathrm{HCl}$. One millicurie lots of ${ }^{14} \mathrm{C}$-bicarbonate were diluted to 1 liter to yield a final concentration of $1 \mu \mathrm{Ci} / \mathrm{ml}$. Two milliliters of the diluted ${ }^{14} \mathrm{C}$ solution was pipetted into $2 \mathrm{ml}$ glass ampules, and the ampules were sealed with a torch. The ampules were autoclaved to check for leaks as well as to make the ${ }^{14} \mathrm{C}$-bicarbonate solution sterile, and then packed for shipment to Africa.

The bicarbonate incubations were conducted at the same time as the glucose uptake incubations were carried out. In as many cases as possible, heterotrophic uptake and primary productivity incubations were carried out on the same water samples. Generally, primary production incubations were conducted on samples collected from 1,2 , and $3 \mathrm{~m}$ below the surface. In about one-third of the experiments, a sample collected either above $1 \mathrm{~m}$ or below $3 \mathrm{~m}$ was also incubated.

Samples were collected with either a 3.5-liter Kemmerer or a 5-liter Niskin bottle. The incubations were conducted as a set of two clear, or "light," bottles and one opaque, or "dark," bottle; the bottles were hard glass $250-\mathrm{ml}$ reagent bottles. Sample water was transferred into the incubation bottles under subdued light. After all bottles were filled, the contents of one ampule containing 2 $\mu \mathrm{Ci}$ of ${ }^{14} \mathrm{C}$-bicarbonate in $2 \mathrm{ml}$ of solution was transferred into each of the incubation bottles. The bottles were then tightly stoppered and attached to a chain and float for incubation in the river at the same depth from which they were collected. Incubation periods were kept to 4 hours or less, with a target of 4 hours.

At the termination of the incubation, the bottles were removed from the river and stored in the dark until the contents were filtered. The radioactivity accumulated by the algae over the course of the incubation was assayed by liquid scintillation counting using the same equipment for the glucose uptake experiments. Each primary productivity bottle was filtered through a $0.45-\mu \mathrm{m}$ pore size Millipore filter which was $4.5 \mathrm{~cm}$ in diameter. Care was taken to keep the sample in the dark during the filtration process; small hoods were placed over the filtration funnels during filtration. After the sample was completely filtered, damp filters were placed into empty scintillation vials and $1 \mathrm{ml}$ of $0.1 \mathrm{~N} \mathrm{HCl}$ was added to the vial. The acid soak removed carbonate buildup on the filter. Filters were allowed to soak for 2 hours and then $10 \mathrm{ml}$ of water-dispersing scintillation cocktail (Amersham, ACS, Arlington Heights, Illinois) was added to each vial.

External standards were prepared for each $1 \mathrm{mCi}$ lot of ${ }^{14} \mathrm{C}$-bicarbonate used overseas. Those external standards were counted at the same time as the samples and used to determine the amount of radioactivity added to each incubation bottle. Water samples for alkalinity determinations were collected and analyzed immediately after incubation samples were placed in the river. In most cases, there was sufficient sample water for alkalinity determinations from the same sample as well as for the primary productivity incubations. The uptake of carbon by algae was computed with the following formula: 
$\underset{\mu \mathrm{g} \text { C/liter } / \text { hour }}{\mathrm{C} \text { uptake in }}=\frac{\text { [light uptake }- \text { dark uptake] } \times \mathrm{W} \times 1.05}{\text { [activity added } \times \text { duration of incubation] }}$

where $\mathrm{W}=$ the weight of carbon in the original water sample as computed from the alkalinity and salinity, and $1.05=$ a factor to correct for the discrimination against the uptake of ${ }^{14} \mathrm{C}$ versus ${ }^{12} \mathrm{C}$ [15].

Results from the primary productivity and glucose uptake experiments were entered into the University of Michigan computing system for more extensive data analyses. The MIDAS software package (Fox DJ and Guire KE, 1976, Documentation for MIDAS, Statistical Research Laboratory, University of Michigan) was used to compute descriptive statistics as well as correlations among uptake values and selected physical, chemical, and biological variables.

\section{Results}

Figure 2 shows the seasonal change in salinity as a function of distance upstream. Table 1, which presents results for the physical and chemical variables in the Gambia River both by season and zone, shows the association between saltwater intrusion and river chemistry.

In general, water temperature was constant with depth during all seasons. Overall river temperatures ranged from 20.5 to $33.0^{\circ} \mathrm{C}$ (mean $=27.4, \mathrm{n}=993$ ). The $\mathrm{pH}$ ranged from 6.3 to 8.1 (mean $=7.5, \mathrm{n}=995$ ) and exhibited a trend of increasing values from near the upper estuary sampling site to the river mouth. The lowest $\mathrm{pH}$ values for the entire Gambia River were observed during the rising and flood stages, and the highest values during the low water stage. Total suspended solids concentrations were generally higher in the estuarine zones and during the flood and low river stages.

Table 2 demonstrates that rain is an important agent involved in the dissolution and transport of dissolved substances; many variables showed large changes immediately after rain. Table 3 summarizes the mean nutrient concentrations at all zones and during the course of the four sampling periods. Total phosphorus (TP), soluble reactive phosphorus (SRP), total nitrogen (TN), and nitrate-nitrogen $\left(\mathrm{NO}_{3}-\mathrm{N}\right)$ concentrations were influenced much more by zone, season, and flow than by transect, station, depth, and tide. One major source of nutrients was runoff, which produced distinct seasonal variations in concentrations. Total nitrogen and nitrate-nitrogen concentrations were extremely variable both spatially and temporally.

Table 4 lists mean values for the biological parameters. The mean number of free bacteria in all areas sampled showed relatively little variation and ranged from $0.94 \times 10^{6}$ cells $/ \mathrm{ml}$ in the lower estuary zone to $1.99 \times 10^{6} \mathrm{cells} / \mathrm{ml}$ in the upper river zone. The mean attached bacteria concentrations varied from a low of $0.04 \times 10^{6}$ cells $/ \mathrm{ml}$ in the upper river zone to a maximum of $0.23 \times$ $10^{6} \mathrm{cells} / \mathrm{ml}$ in the upper estuary zone. The ratio of free bacteria to attached bacteria decreased markedly from the upper river to the lower estuary. This ratio was between six and nine times greater during the declining and low water periods than during the rising and flood water periods. Figure 3 shows the progressive decline of free bacteria densities from the freshwater to the estuarine zones and the concomitant increase in attached bacteria densities.

There was an indication that free and attached bacteria concentrations were 


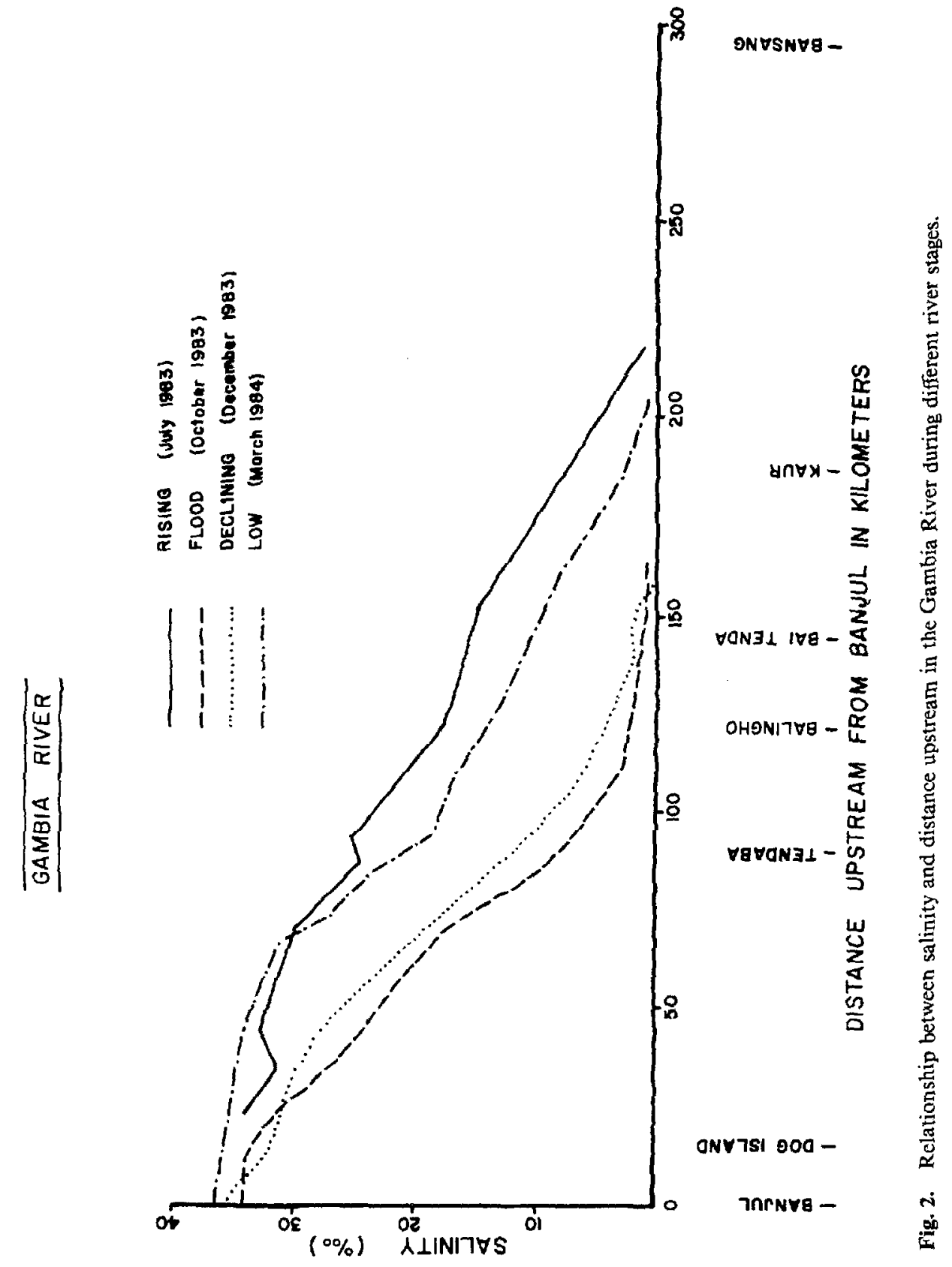


Table 1. Range, mean values, and number of observations for physical and chemical measurements at cach zone and during each river stage sampled, Gambia River, 1983-84

\begin{tabular}{|c|c|c|c|c|}
\hline Station & $\begin{array}{l}\text { Salinity }(\% \text { S) or } \\
\text { conductivity } \\
(\mu \text { mhos } / \mathrm{cm})\end{array}$ & $\begin{array}{c}\text { Temperature } \\
\left({ }^{\circ} \mathrm{C}\right)\end{array}$ & $\mathrm{pH}$ & $\begin{array}{l}\text { Total suspended } \\
\text { solids (mg/liter) }\end{array}$ \\
\hline Upper river & $\begin{array}{l}(35-104)^{a} \\
55 \\
n=100\end{array}$ & $\begin{array}{c}(20.5-33.0) \\
26.6 \\
n=100\end{array}$ & $\begin{array}{c}(6.4-8.0) \\
7.2 \\
n=102\end{array}$ & $\begin{array}{c}(1-190) \\
36 \\
n=94\end{array}$ \\
\hline Lower river & $\begin{array}{c}(42-92)^{\alpha} \\
60 \\
\mathrm{n}=312\end{array}$ & $\begin{array}{c}(25.0-31.2) \\
28.8 \\
\mathrm{n}=312\end{array}$ & $\begin{array}{c}(6.3-7.8) \\
7.4 \\
n=311\end{array}$ & $\begin{array}{c}(14-50) \\
25 \\
\mathrm{n}=312\end{array}$ \\
\hline Upper estuary & $\begin{array}{c}(0.1-14.5) \\
8.1 \\
n=254\end{array}$ & $\begin{array}{c}(23.6-31.0) \\
27.6 \\
\mathrm{n}=312\end{array}$ & $\begin{array}{c}(7.0-7.6) \\
7.2 \\
n=312\end{array}$ & $\begin{array}{c}(11-498) \\
75 \\
n=308\end{array}$ \\
\hline Lower estuary & $\begin{array}{c}(28.7-35.3) \\
33.3 \\
n=270\end{array}$ & $\begin{array}{c}(20.8-33.0) \\
26.0 \\
\mathbf{n}=269\end{array}$ & $\begin{array}{c}(7.7-8.1) \\
7.9 \\
\mathrm{n}=270\end{array}$ & $\begin{array}{c}(8-517) \\
84 \\
\mathbf{n}=267\end{array}$ \\
\hline \multicolumn{5}{|l|}{ River stage } \\
\hline Rising & $\begin{array}{c}(12.2-33.8) \\
19.6 \\
n=104\end{array}$ & $\begin{array}{c}(28.5-33.0) \\
30.6 \\
n=200\end{array}$ & $\begin{array}{c}(6.3-8.0) \\
7.4 \\
\mathrm{n}=200\end{array}$ & $\begin{array}{c}(11-220) \\
32 \\
n=172\end{array}$ \\
\hline Flood & $\begin{array}{c}(0.1-34.0) \\
25.4 \\
n=122\end{array}$ & $\begin{array}{c}(26.2-33.0) \\
29.8 \\
\mathbf{n}=255\end{array}$ & $\begin{array}{c}(6.5-7.9) \\
7.4 \\
n=269\end{array}$ & $\begin{array}{c}(20-224) \\
69 \\
n=270\end{array}$ \\
\hline Declining & $\begin{array}{c}(1.4-35.3) \\
17.6 \\
\mathrm{n}=158\end{array}$ & $\begin{array}{c}(20.8-29.7) \\
25.8 \\
n=270\end{array}$ & $\begin{array}{c}(6.8-8.1) \\
7.5 \\
\mathrm{n}=270\end{array}$ & $\begin{array}{c}(1-498) \\
49 \\
n=268\end{array}$ \\
\hline Low & $\begin{array}{c}(9.9-34.8) \\
22.6 \\
\mathrm{n}=160\end{array}$ & $\begin{array}{c}(20.5-29.0) \\
24.6 \\
n=268\end{array}$ & $\begin{array}{c}(6.7-8.0) \\
7.6 \\
\mathrm{n}=256\end{array}$ & $\begin{array}{c}(1-517) \\
71 \\
\mathrm{n}=271\end{array}$ \\
\hline
\end{tabular}

${ }^{a}$ Conductivity

Table 2. The percent change in silica and nitrate-nitrogen concentrations at each zone and during each river stage sampled, Gambia River, 1983-84

\begin{tabular}{|c|c|c|c|c|c|}
\hline \multirow[b]{2}{*}{ Variable } & \multirow[b]{2}{*}{ Zone } & \multirow{2}{*}{$\begin{array}{c}\begin{array}{c}\text { Concen- } \\
\text { tration }^{a, b}\end{array} \\
\text { Rising }\end{array}$} & \multicolumn{3}{|c|}{$\begin{array}{l}\% \text { Change of variable } \\
\text { compared to rising water }\end{array}$} \\
\hline & & & Flood & Declining & Low \\
\hline \multirow[t]{4}{*}{ Silica $^{a}$} & Lower estuary & 1.4 & 30.4 & 23.0 & 37.0 \\
\hline & Upper estuary & 8.8 & 49.0 & 75.2 & 41.4 \\
\hline & Lower river & 4.0 & 262.5 & 220.2 & 282.0 \\
\hline & Upper river & 8.7 & 38.8 & 33.6 & 57.0 \\
\hline \multirow{4}{*}{$\begin{array}{l}\text { Nitrate- } \\
\quad \text { nitrogen }^{b}\end{array}$} & Lower estuary & 7.6 & 199.7 & 612.9 & 218.4 \\
\hline & Upper estuary & 66.8 & 226.8 & 205.8 & -36.0 \\
\hline & Lower river & 74.2 & 23.9 & -98.1 & -100.0 \\
\hline & Upper river & 49.2 & -80.2 & -100.0 & -90.4 \\
\hline
\end{tabular}

${ }^{a}$ Concentration in $\mathrm{mg} /$ liter (silica)

${ }^{b}$ Concentration in $\mu \mathrm{g} /$ liter (nitrate-nitrogen) 
Table 3. Range, mean values, and number of observations for nutrients at each zone and during each river stage sampled, Gambia River, 1983-84

\begin{tabular}{lcccc}
\hline Station & $\begin{array}{c}\text { Total phosphorus } \\
(\mu \mathrm{g} / \text { liter })\end{array}$ & $\begin{array}{c}\text { Soluble reactive } \\
\text { phosphorus } \\
(\mu \mathrm{g} / \text { liter })\end{array}$ & $\begin{array}{c}\text { Total nitrogen } \\
(\mu \mathrm{g} / \text { liter })\end{array}$ & $\begin{array}{c}\text { Nitrate-nitrogen } \\
(\mu \mathrm{g} / \text { liter })\end{array}$ \\
\hline Upper river & $(6.9-149.5)$ & $(0.01-20)$ & $(86-785.6)$ & $(0.01-85.0)$ \\
& 31.7 & 3.0 & 254.3 & 13.0 \\
Lower river & $\mathrm{n}=84$ & $\mathrm{n}=77$ & $\mathrm{n}=84$ & $\mathrm{n}=76$ \\
& $(5.6-46.3)$ & $(0.1-3.84)$ & $(5.1-633.2)$ & $(0.01-121.9)$ \\
Upper estuary & 27.5 & 1.6 & 216.6 & 41.4 \\
& $\mathrm{n}=188$ & $\mathrm{n}=291$ & $\mathrm{n}=188$ & $\mathrm{n}=309$ \\
Lower estuary & $(10.7-225)$ & $(0.6-15.1)$ & $(117.6-557.2)$ & $(28.8-235.2)$ \\
& 49.9 & 6.5 & 341.9 & 134.7 \\
River stage & $\mathrm{n}=205$ & $\mathrm{n}=308$ & $\mathrm{n}=206$ & $\mathrm{n}=308$ \\
Rising & $(16.8-215.9)$ & $(13.8-28.4)$ & $(165-904.6)$ & $(0.3-74.2)$ \\
& 58.2 & 22.3 & 347.7 & 30.6 \\
& $\mathrm{n}=171$ & $\mathrm{n}=269$ & $\mathrm{n}=172$ & $\mathrm{n}=268$ \\
Flood & & & & \\
& $(10.7-155.2)$ & $(0.01-27.2)$ & $(114.2-633.2)$ & $(0.01-121.9)$ \\
& 31.3 & 7.6 & 299.9 & 58.4 \\
Declining & $\mathrm{n}=151$ & $\mathrm{n}=169$ & $\mathrm{n}=152$ & $\mathrm{n}=186$ \\
& $(18.4-100.2)$ & $(0.1-28.1)$ & $(143.5-785.6)$ & $(0.01-235.3)$ \\
& 46.9 & 8.9 & 338.5 & 98.0 \\
Low & $\mathrm{n}=261$ & $\mathrm{n}=270$ & $\mathrm{n}=263$ & $\mathrm{n}=270$ \\
& $(6.9-225)$ & $(0.4-28.4)$ & $(5.1-467.7)$ & $(0.01-210.7)$ \\
& 42.7 & 11.5 & 199.6 & 88.3 \\
& $\mathrm{n}=125$ & $\mathrm{n}=236$ & $\mathrm{n}=124$ & $\mathrm{n}=234$ \\
& $(5.6-215.9)$ & $(0.25-24.7)$ & $(47.7-904.6)$ & $(0.01-63.6)$ \\
& 51.3 & 8.5 & 296.7 & 20.3 \\
& $\mathrm{n}=111$ & $\mathrm{n}=270$ & $\mathrm{n}=111$ & $\mathrm{n}=271$ \\
\hline
\end{tabular}

not always homogeneous. Table 5 presents the results of the ANOVA from the Greco-Latin Square design. These results showed that relatively few of the main effects (blocking variables) caused significant changes in either attached or free bacteria concentrations. Sixteen ANOVAs were conducted with four $F$-tests per analysis for free bacteria concentrations and likewise for attached bacteria abundances. The results showed that only $8 F$-tests of the total 128 were significant at the 0.05 probability level. The lack of significant $F$-tests appeared to originate from high within group variability rather than lack of variation among the blocking variables.

Glucose uptake increased dramatically, from August (rising water) to March (low water) in all zones except the lower estuary zone, and values were approximately three times higher in March than in August (Fig. 4). The spatial trend was even more pronounced, with the lowest uptake rates observed in the lower estuary, followed by progressively higher rates in the lower river, the upper estuary, and the upper river zones. Spatial and temporal trends in glucose uptake are much more apparent when plotted by season versus zone (Fig. 4). 
M. J. Healey et al.

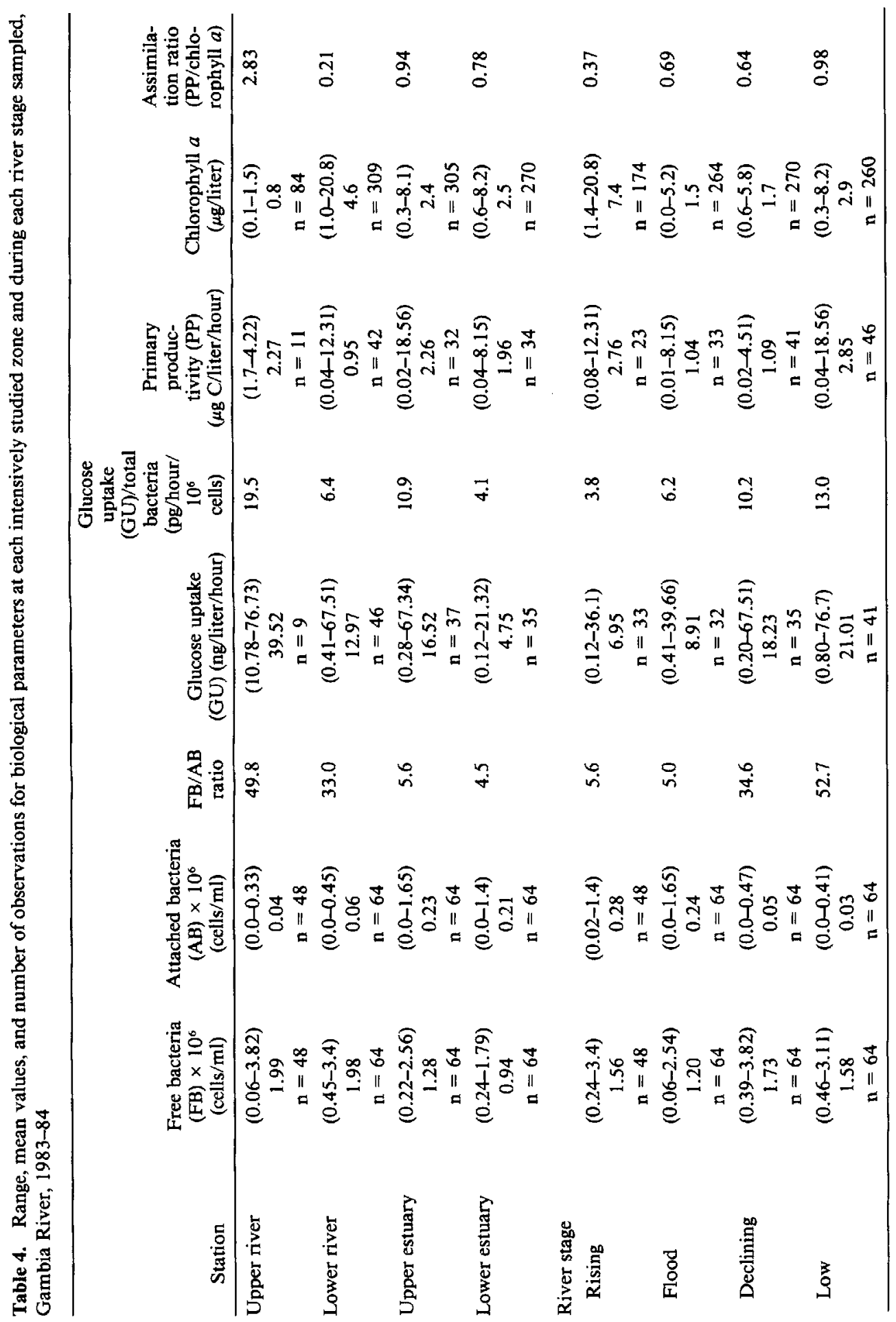




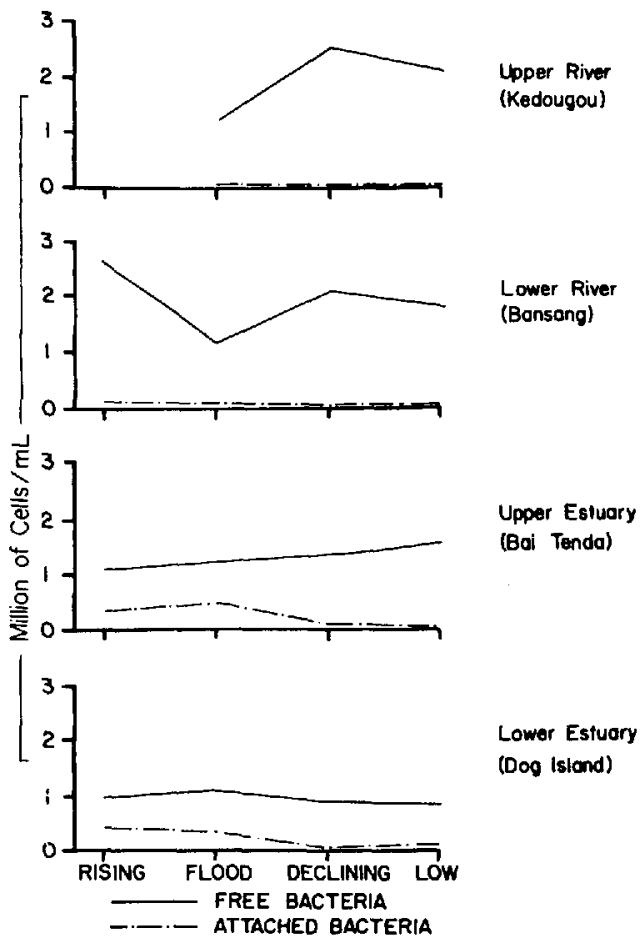

Fig. 3. Concentration of free and attached bacteria in relation to different river stages at four intensively studied zones on the Gambia River, 1983-1984.

Table 5. Significant $(P<0.05)$ differences in free bacteria $(\mathrm{FB})$ and attached bacteria $(A B)$ concentrations in relation to spatial and temporal variables, Gambia River, 1983-84

\begin{tabular}{lllc}
\hline & \multicolumn{1}{c}{ Rising } & Flood & Low \\
\hline Upper estuary & AB; transect & & FB; station, tide, depth \\
Lower estuary & AB; transect, tide & FB; station & \\
Upper river & & FB; station & \\
\hline
\end{tabular}

Trends in the ratio of glucose uptake to total bacteria corresponded to those exhibited by glucose uptake [22]: a steady increase from the rising to low river stages and smaller ratios in the lower river and the lower estuary as compared with the upper river and the upper estuary.

${ }^{14} \mathrm{C}$-uptake was low during the flood and declining waters (October and December) and over two times higher during rising and low waters (August and March) (Table 4). On a spatial basis, ${ }^{14} \mathrm{C}$-uptake exhibited similar trends, except for the lower estuary zone. When viewed on a zone by cruise basis (Fig. 5 ), it was apparent that uptake rates were high at all zones during rising waters.

Chlorophyll $a$ concentrations exhibited large changes over short distances when samples between intensively studied zones were compared. Concentrations of chlorophyll $a$ were highest during the rising and low water periods when streamflows were at or nearest the lowest point (Table 4). On a spatial 

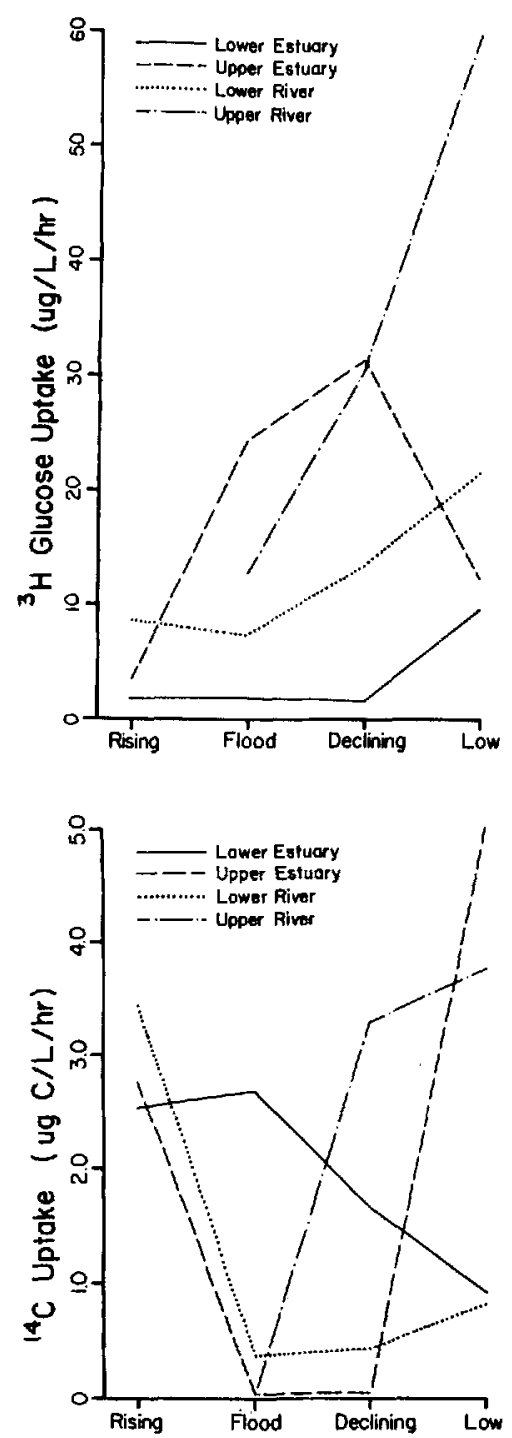

Fig. 4. Uptake of ${ }^{3} \mathrm{H}$ in relation to different river stages at four intensively studied zones on the Gambia River, 1983-1984.
Fig. 5. Uptake of ${ }^{14} \mathrm{C}$ in relation to different river stages at four intensively studied zones on the Gambia River, 1983-1984.

basis, chlorophyll $a$ concentrations were comparable in the two estuarine zones, almost twice as high in the lower river zone which exhibited some of the highest phytoplankton counts ( $>10^{4} \mathrm{cells} / \mathrm{ml}$ on one occasion) in the entire study, and lowest in the upper river zone.

Similar to glucose uptake data, the ${ }^{14} \mathrm{C}$-bicarbonate uptake results can be presented as a ratio of uptake to biomass. These assimilation ratios showed that productivity per unit biomass was fairly uniform among seasons, but very different among zones (Table 4). Seasonally, the ratios varied from 0.37 to 0.98 , which indicated that the ratios exhibited little seasonality in primary productivity. Spatial variations were greater, with the lowest values found in 
Table 6. Phytoplankton carbon : bacteria ratios for different river stages and locations in the Gambia River, 1983-84

\begin{tabular}{cccc}
\hline \multicolumn{5}{c}{ Season } \\
\hline $\mathrm{R}$ & $\mathrm{F}$ & $\mathrm{D}$ & $\mathrm{L}$ \\
\hline 8.65 & 2.56 & 2.83 & 4.54 \\
& & & \\
& & Zone & \\
\hline LE & UE & LR & UR \\
\hline 6.22 & 3.90 & 5.46 & 1.07 \\
\hline
\end{tabular}

Estimates of carbon were derived by converting chlorophyll concentrations and bacteria cell counts according to Rublee [13]

Season: $R=$ rising, $F=$ flood, $D=$ declining, $L=$ low; Zone: $\mathrm{LE}=$ lower estuary, $\mathrm{UE}=$ upper estuary, $\mathrm{LR}=$ lower river, $U R=$ upper river

the lower river zone $(0.21)$ and the highest values (2.83) found in the upper river zone. All these values were low compared with other environments [19].

Converting the bacteria counts and chlorophyll measurements to carbon allows comparison of the two trophic levels with common units. For the bacteria to carbon conversion, the volume of a cell was assumed to be $0.221 \mu \mathrm{m}^{3}$ and the amount of carbon was assumed to be $0.099 \mathrm{~g} \mathrm{C} / \mathrm{ml}$; chlorophyll carbon was estimated by multiplying by the factor 60 [13]. The results (Table 6) show that for much of the year and at most locations, phytoplankton biomass was about two to eight times bacteria biomass. In the upper river zone, phytoplankton and bacterial biomass were nearly equal. Free bacteria densities were negatively correlated with chemical parameters that were associated with sea water: salinity, conductivity, $\mathrm{pH}$, and alkalinity (Table 7). Attached bacteria were positive correlates with conductivity and alkalinity.

Phytoplankton abundance was highly correlated with salinity, chlorophyll, and temperature and negatively correlated with other variables. Many of these patterns did not persist among zones and seasons, whereas others were very consistent.

\section{Discussion}

The Gambia River extends over $1,100 \mathrm{~km}$ from its source near Labe to the mouth at Banjul. Because the lower portion of the river flows through flat terrain, tidal waves are propagated over $500 \mathrm{~km}$ upstream. Tidal ranges are large throughout most of the tidal portion of the river, exceeding $1 \mathrm{~m}$ over 300 $\mathrm{km}$ upstream. The river exhibits year-round flow even during periods of extreme drought (Harza Engineering Company International, 1985, Gambia River Basin : Hydrology, Gambia River Studies Working Document No. 53, CRED, The University of Michigan, Ann Arbor, Michigan).

Saltwater intrusion is a fundamental aspect of the ecology of the Gambia 
Table 7. Correlation coefficients among free and attached bacteria concentrations, ${ }^{3} \mathrm{H}$ glucose uptake, ${ }^{14} \mathrm{C}$ uptake, phytoplankton abundance, and biological, physical, and chemical variables

\begin{tabular}{|c|c|c|c|c|c|}
\hline Variable & Free bacteria & $\begin{array}{l}\text { Attached } \\
\text { bacteria }\end{array}$ & $\begin{array}{c}{ }^{3} \mathrm{H} \text { glucose } \\
\text { uptake }\end{array}$ & ${ }^{14} \mathrm{C}$ uptake & $\begin{array}{c}\text { Phytoplankton } \\
\text { counts }\end{array}$ \\
\hline Depth of sample & - & - & $\begin{array}{l}0.3332^{a} \\
(119)\end{array}$ & $\begin{array}{l}-0.3320^{a} \\
(108)\end{array}$ & - \\
\hline Conductivity & $\begin{array}{c}-0.2977^{a} \\
(175)\end{array}$ & $\begin{array}{l}0.1697^{c} \\
(175)\end{array}$ & - & $\begin{array}{l}0.3814^{a} \\
(74)\end{array}$ & $\begin{array}{l}-0.2201^{b} \\
(175)\end{array}$ \\
\hline Salinity & $\begin{array}{c}-0.3659^{a} \\
(116)\end{array}$ & - & $\begin{array}{c}-0.5410^{a} \\
(73)\end{array}$ & - & $\begin{array}{l}0.4148^{a} \\
(115)\end{array}$ \\
\hline Temperature & - & $\begin{array}{l}0.3539^{a} \\
(240)\end{array}$ & - & - & $\begin{array}{l}0.3978^{a} \\
(239)\end{array}$ \\
\hline $\mathrm{pH}$ & $\begin{array}{c}-0.2963^{a} \\
(240)\end{array}$ & - & $\begin{array}{l}-0.2270^{\circ} \\
(119)\end{array}$ & - & $\begin{array}{l}-0.3843^{a} \\
(239)\end{array}$ \\
\hline Alkalinity & $\begin{array}{l}-0.4933^{a} \\
(240)\end{array}$ & $\begin{array}{l}0.1915^{h} \\
(240)\end{array}$ & $\begin{array}{l}-0.3012^{a} \\
(119)\end{array}$ & $\begin{array}{l}0.2103^{c} \\
(108)\end{array}$ & $\begin{array}{l}-0.2839^{a} \\
(239)\end{array}$ \\
\hline Dissolved oxygen & $\begin{array}{l}0.1387^{c} \\
(240)\end{array}$ & $\begin{array}{l}-0.2091^{\circ} \\
(240)\end{array}$ & $\begin{array}{l}-0.3680^{a} \\
(119)\end{array}$ & - & - \\
\hline Suspended solids & $\begin{array}{c}-0.3228^{a} \\
(236)\end{array}$ & $\begin{array}{l}0.1497^{c} \\
(236)\end{array}$ & $\begin{array}{l}0.2333 r \\
(119)\end{array}$ & - & - \\
\hline Soluble silica & $\begin{array}{l}-0.2636^{a} \\
(240)\end{array}$ & $\begin{array}{l}-0.1886^{b} \\
(240)\end{array}$ & $\begin{array}{l}0.4146^{a} \\
(119)\end{array}$ & - & - \\
\hline $\begin{array}{l}\text { Soluble reactive } \\
\text { phosphorus }\end{array}$ & $\begin{array}{l}-0.502^{a} \\
(220)\end{array}$ & $\begin{array}{l}0.2031^{b} \\
(220)\end{array}$ & $\begin{array}{l}-0.2610^{b} \\
(119)\end{array}$ & - & $\begin{array}{l}-0.3226^{4} \\
(219)\end{array}$ \\
\hline Total phosphorus & $\begin{array}{l}-0.3443^{a} \\
(226)\end{array}$ & $\begin{array}{l}0.1849^{\prime \prime} \\
(226)\end{array}$ & . - & - & - \\
\hline Ammonia nitrogen & - & - & - & - & $\begin{array}{c}-0.3622^{a} \\
(92)\end{array}$ \\
\hline Nitrate nitrogen & - & - & $\begin{array}{l}0.3239^{a} \\
(119)\end{array}$ & - & $\begin{array}{l}-0.2406^{a} \\
(223)\end{array}$ \\
\hline Total nitrogen & $\begin{array}{l}-0.3379^{a} \\
(224)\end{array}$ & $\begin{array}{l}0.232^{a} \\
(224)\end{array}$ & $\begin{array}{l}-0.2073^{r} \\
(119)\end{array}$ & - & - \\
\hline Chlorophyll $a$ & $\begin{array}{l}0.2651^{a} \\
(238)\end{array}$ & - & - & $\begin{array}{l}0.337^{a} \\
(108)\end{array}$ & $\begin{array}{l}0.5327^{a} \\
(237)\end{array}$ \\
\hline Phaeopigments & $\begin{array}{l}-0.2109^{\circ} \\
(238)\end{array}$ & $\begin{array}{l}0.2573^{a} \\
(238)\end{array}$ & - & - & - \\
\hline Attached bacteria & $\begin{array}{c}-0.2629^{a} \\
(240)\end{array}$ & - & $\begin{array}{l}-0.1954^{c} \\
(119)\end{array}$ & - & - \\
\hline Free bacteria & - & - & - & - & $\begin{array}{l}0.2374^{a} \\
(240)\end{array}$ \\
\hline
\end{tabular}

${ }^{a} P<0.001 ;{ }^{h} P<0.01 ;{ }^{c} P<0.05$. Values in parentheses indicate number of pairs of observations

River, and it controls the nature of the aquatic flora and fauna. The details vary among years because of the magnitude of the annual flood, but a basic pattern has emerged. Saltwater reaches its maximum penetration in early June and the boundary between freshwater and saltwater remains more or less stationary until mid-August (Harza Engineering Company International, 1985, Gambia River Basin: Hydrology, Gambia River Studies Working Document No. 53, CRED, The University of Michigan, Ann Arbor, Michigan) (Fig. 2). 
The annual flood rapidly pushes the salt frontier downstream to its minimum penetration in September. That location depends greatly upon the size of the flood, but recently it has been located near 70 and near $130 \mathrm{~km}$ above the river mouth (1983 and 1984, respectively).

After the passage of the flood, salt water begins to move back upstream in October. Between October and June, the salt frontier moves upstream at an average rate of $15 \mathrm{~km} /$ month, increasing to $20 \mathrm{~km} /$ month at the end of the dry season. Longitudinal salinity gradients ranged from $0.40 \% \mathrm{~S} / \mathrm{km}$ to $0.17 \%$ $\mathrm{S} / \mathrm{km}$ in September and May, respectively (Howard Humphreys Limited, 1984, The autonomous operation of the Kekreti Reservoir, Report to OMVG, Reading, England).

The lower estuary zone is an extension of the sea into a wide slow-flowing tidally dominated river. Even during the height of the flood the chemical characteristics of this zone are similar to those of the coastal oceanic environment. The thermal regime is controlled by the North Equatorial Current [16], and many other chemical characteristics such as salinity, $\mathrm{pH}$, alkalinity, dissolved oxygen, total phosphorus, and soluble reactive phosphorus were also dominated by the coastal ocean waters. Short-term temporal and spatial variation of the concentrations of dissolved and suspended materials is ultimately controlled by the dynamic interplay between the ocean, the tides, and meterologic seasons.

The dominant physical force in the upper estuary zone is tidal mixing. Tidal and river currents in the main river channel often exceed $1.5 \mathrm{~m} / \mathrm{sec}$. These currents produce sufficient mixing to keep the concentrations of dissolved substances and temperature uniform throughout the water column. The seasonal pattern of the thermal cycle stands in contrast to the streamflow and exerts great control over the physical-chemical variables. The high degree of tidal mixing obscures most patterns of small-scale spatial variability.

Short-term temporal variability was an important factor as movement of water along the river and its adjoining creek produced large changes in physicalchemical parameters. In particular, $\mathrm{pH}$, dissolved oxygen, and sulfate decreased upstream in the mangrove-lined tidal creeks (bolons), and this was attributed to the high level of biological activity in these organic-rich areas (Twilley RR, 1985, Great Lakes and Marine Waters Center International Program, Report No. 6, The University of Michigan, Ann Arbor, Michigan).

Mangrove forests extend from the river mouth to the extreme extent of saltwater penetration, about $250 \mathrm{~km}$ upstream. These systems exhibit smallto-moderate changes in most variables over one tidal cycle, but enormous changes upstream in the bolons (Berry TD, Moll RA, Krausse GL, 1985, Great Lakes and Marine Waters Center International Program, Report No. 9, The University of Michigan, Ann Arbor, Michigan). Large changes in nitrate-nitrogen and silica concentrations indicate extreme biological community activity. The changes in nitrate-nitrogen concentrations in the bolons relative to the main channel involved a decrease of over one order of magnitude, and occurred during the day and night and during high and low tides. These changes have been attributed to denitrification (Twilley RR, 1985, Great Lakes and Marine Waters Center International Program, Report No. 6, The University of Michigan, Ann Arbor, Michigan).

The lower freshwater zone, located between 250 and $500 \mathrm{~km}$ upstream, also 
displays a distinct hydrologic seasonality. As with the other freshwater zones, the thermal cycle is the only physical-chemical variable not controlled by the hydrologic cycle. Tidal currents are evident in this lower freshwater portion of the river, although much weaker than in the estuarine zones.

The upper freshwater zone was located $500-1,000 \mathrm{~km}$ from the river mouth. A major distinction between this zone and the lower freshwater zone was the lack of tidal waves in the former. Seasonality controlled physical and chemical water quality characteristics, except for temperature which showed little seasonal change. Many variables showed large changes immediately after rain and emphasized the importance of rain as a transport agent for dissolved substances such as silica and nitrate-nitrogen (Table 2) [17].

In the headwaters zone, which begins over $900 \mathrm{~km}$ from the river mouth, the dendritic network of small streams and the sharp elevation drop (average is $4.2 \mathrm{~m} / \mathrm{km}$ ) are the dominant features. As in the upper freshwater zone, the annual pattern of wet and dry season controlled the water chemistry (Berry TD et al., 1985, Great Lakes and Marine Waters Center International Program, Report No. 9, The University of Michigan, Ann Arbor, Michigan). Temperatures in the upper river zone were the most variable of all the zones, both among different field trips and within each field trip. In the lower river, temperatures were consistently higher than in the upper estuary. Temperatures in both these zones decreased each successive field trip. Water temperatures in the lower estuary zone were influenced primarily by the ocean. Seasonal changes in temperature occurred more slowly in the lower estuary and upper river zones than in the upper estuary and lower river zones.

The upper portion of the Gambia River carries a relatively low sediment load due to its rock-lined bottom and low streamflows during the dry season (Harza Engineering Company International, 1985, Gambia River Basin: Hydrology, Gambia River Studies Working Document No. 53, CRED, The University of Michigan, Ann Arbor, Michigan).

Suspended sediment loads in the Gambia River were extremely low during the dry season, never exceeding $50 \mathrm{mg} /$ liter in the freshwater portion of the river, although typically exceeding $75 \mathrm{mg} /$ liter in the estuarine portions of the river. These higher estuarine sediment loads were attributed to tidal currents scouring soft bottom sediments.

Total phosphorus and soluble reactive phosphorus concentrations were highly correlated with seawater (Berry TD et al., 1985, Great Lakes and Marine Waters Center International Program, Report No. 9, The University of Michigan, Ann Arbor, Michigan). Nitrate-nitrogen values were low in all zones except in the upper estuary. This suggested that there were local sources of soluble nitrate-nitrogen in this mangrove-dominated zone.

Results of the ANOVA (Table 5) indicated that the river environment was not completely homogeneous with respect to free and attached bacteria populations, especially in the three zones that were tidally mixed. This is not surprising in view of the heterogeneous character within and among the river zones. For example, in the lower estuary, the river mouth is up to $15 \mathrm{~km}$ wide and has extensive mud flats that are alternately exposed and covered during the tidal cycle.

The ranges of the bacterioplankton concentrations were similar to those of other African rivers and point toward a dominant factor that regulates abun- 
dances, such as substrate availability and/or predation $[1,25]$. Seasonal changes in free bacteria densities were small, but attached bacteria concentrations were distinctly higher during the rising (July) and flood (October) water stages when suspended solids concentrations were at their annual maximum. Free bacteria concentrations were over two times higher in the upper river zone than in the lower estuary zone and attached bacteria concentrations were four times greater in the estuarine zones than in the freshwater zones. The decrease in free bacteria densities may be due to the fact that predominantly fresh water bacteria washed down into the estuary were rendered nonviable by the higher salt concentrations. These differences suggest that hydrologic and edaphic factors are responsible and reflect the importance of organic particle-associated bacteria in the mangrove-dominated estuarine zone.

The correlations among free bacteria densities, glucose uptake rates, and physical and chemical variables suggested that free bacteria and glucose uptake decreased with increased salinity, an observation also made by other investigators $[3,12,24]$. A decrease in glucose uptake in higher salinity water may reflect the fact that many marine bacteria cannot utilize glucose.

Free bacteria were found in greater densities when there were higher concentrations of chlorophyll $a$, which was usually adjacent to luxuriant mangrove forests. The correlations also showed that attached bacterial concentrations were elevated when suspended solids and phaeopigments, the degradation products of chlorophyll-bearing organisms, were present in high concentrations. These observations point toward substrate availability as a key variable in determining the densities of free and attached bacteria.

Rates of ${ }^{3} \mathrm{H}$-glucose uptake and uptake on a per cell basis increased uniformly from the rising waters season through the flood to the low waters period. Uptake rates were highest in the upper river zone and lowest in the lower estuary zone. These findings show that there were more metabolically active populations during the low water period and in the upper river zone.

Positive correlations among glucose uptake rates, attached bacteria, and suspended solids concentrations indicated that the highest rates of glucose uptake were observed in conjunction with attached bacteria and suspended solids. In contrast, the highest suspended solids concentrations were found in the lower estuary, the zone with the lowest uptake rates per cell. The low glucose uptake rates in the lower estuary, a zone which is an extension of the sea, may, again, reflect the fact that many marine bacteria cannot utilize glucose. These results suggest that particle-associated bacteria, on the whole, were important, metabolically active members of the plankton assemblage.

Strong correlations among phytoplankton abundance, free bacteria densities, and chlorophyll $a$ concentrations suggest that the presence of high algal densities contributed to bacterial secondary production. Primary productivity estimates indicated that the depth of the photic zone in the Gambia River was consistently less than $1 \mathrm{~m}$. Higher ${ }^{3} \mathrm{H}$-glucose uptake rates and lower ${ }^{14} \mathrm{C}$-uptake rates were observed with increasing depth. These correlations appeared to arise from slightly higher bacterial biomass and lower phytoplankton biomass with increasing depth. Given that algal biomass as measured both by chlorophyll $a$ and cell counts was low by limnological standards [19] and that bacterial biomass (as estimated by AODC) and glucose uptake was high, the dominance of heterotrophy over autotrophy emerges. 
Primary productivity rates and chlorophyll $a$ concentrations exhibited similar trends temporally. Both measurements were highest during the rising and low water periods when the Gambia River waters were clearer than during the flood and declining water periods when the river was turbid. On a spatial basis, primary productivity rates and chlorophyll a concentrations were similar in both estuarine zones. The lowest primary productivity rates were found in the lower river zone which, during a different time of the year, also exhibited the highest phytoplankton and chlorophyll $a$ concentrations. The highest primary productivity rates were associated with the lowest chlorophyll $a$ concentrations and lower phytoplankton densities in the upper river zone. It is also possible that the observed algal biomass was produced elsewhere and washed into the lower river zone.

Primary productivity rates were high in all zones during the rising water period. Rates decreased to an annual low in all zones except the lower estuary zone during the flood period. The decrease in primary productivity rates during the flood was most likely attributable to high turbidity. The rates of primary production increased in all zones except the lower estuary zone after the flood. The conclusion from these observations was that the lower estuary zone acted out of concert with the other zones because it was controlled by different forces. Intrusion of coastal marine waters carried a distinct marine chemistry and flora which was primarily unaffected by the annual flood.

Assimilation ratios demonstrated that productivity per unit biomass was similar among seasons, but very different among zones. The two estuarine zones exhibited similar low values. The lowest value was exhibited by the lower river zone and the highest value was found in the upper river zone. With the exception of the assimilation ratio value of 2.83 found in the upper freshwater river zone, these values were low when compared with other environments [19]. This was equally true for phytoplankton abundance and was probably due to highly turbid water with low light penetration.

The negative correlation of phytoplankton abundance with conductivity and salinity reflected the fact that algal densities were higher in the freshwater portions of the river. This was probably due to extensive tidal mixing in the estuarine zones which served to decrease light penetration and algal growth. The decrease in primary productivity with depth most likely also reflected increased light attenuation.

Conversion of bacteria counts and chlorophyll measurements to carbon permitted comparison of the two trophic levels and showed that the algal biomass was two to eight times greater than bacterial biomass at three of the four zones and during the four river stages. Taking into account the high metabolic activity of the bacteria, the dominance of heterotrophy over autotrophy became evident. This was confirmed by diel free-water oxygen measurements for estimating productivity which showed only a small portion $(<1 \mathrm{~m})$ of the water column was euphotic. The warm nonproductive river water clearly supported high levels of heterotrophy which was fueled by large inputs of mangrove detritus (Twilley RR, 1985, Great Lakes and Marine Waters Center International Program, Report No. 6, The University of Michigan, Ann Arbor, Michigan, 75 pp.).

The conclusion from these data is that the ecological structure of the Gambia River appears geared toward heterotrophic activity associated with degradation 
of the year-round mangrove litterfall and occasional large but brief inputs of algal primary productivity. Mangrove detritus served as the primary source of energy for bacteria which in turn served as food for higher trophic levels. This observation is corroborated by the fact that detritivores were dominant members of the vertebrate and invertebrae fauna (Van Maren MJ, Report No. 4, and Dorr JA et al., Report No. 11, 1985, Great Lakes and Marine Waters Center International Program, The University of Michigan, Ann Arbor, Michigan). The lower estuary zone acted out of concert with the other zones in that bacteria populations were smaller than in the rest of the river, whereas algal populations were comparable. Therefore, autotrophy may play a relatively more important role in this zone.

Acknowledgments. Studies of the Gambia River Basin by the University of Michigan were supported by the River Basin Development Office (RBDO), Dakar, Senegal, of the United States Agency for International Development under contract no. 685-0012-C-2158. Any opinions, findings, and conclusions or recommendations expressed in this publication are those of the authors and do not reflect the views of the United States Agency for International Development.

\section{References}

1. Azam F, Fenche1 T, Field JH, Gray JS, Meyer-Reil LA, Thingstad F (1983) The ecological role of water-column microbes in the sea. Mar Ecol Progr Ser 10:257-263

2. Azam F, Holm-Hansen $O$ (1973) Use of tritiated substances in the study of heterotrophy in seawater. Mar Biol 23:191-196

3. Bell CR, Albright LJ (1981) Attached and free-floating bacteria in the Fraser River estuary, British Columbia, Canada. Mar Ecol Progr Ser 6:317-327

4. D'Elia CF, Stendler PA, Corwin N (1977) Determination of total nitrogen in aqueous samples using persulfate digestion. Limnology and Oceanography 22:760-764

5. Hall CAS, Moll RA (1975) Methods of assessing aquatic primary productivity. In: Leith $\mathrm{H}$. Whittaker RH (eds) Primary productivity of the biosphere. Springer-Verlag, New York, pp 19-52

6. Hobbie JE, Crawford CC (1969) Respiration corrections for bacterial uptake and dissolved organic compounds in natural waters. Limnology and Oceanography 14:528-532

7. Hobbie JE, Daley RJ, Jasper S (1977) Use of Nucleopore filters for counting bacteria by epifluorescence microscopy. Appl Environ Microbiol 33:1225-1228

8. Imevbore AMA, Bakare O (1974) A pre-impoundment study of the swamps in the Kainji Lake basin. Afr J Trop Hydrobiol Fish 3, 1:79-93

9. Menzel DW, Corwin N (1965) The measurement of total phosphorus in seawater based on the liberation of organically bound fractions by persulfate oxidation. Limnology and Oceanography 10:280-281

10. Neter J, Wasserman W (1974) Applied linear statistical models. Richard D. Irwin, Inc, Homewood, Illinois

11. Nixon SW (1981) Remineralization and nutrient cycling in coastal marine ecosystems. In: Neilson BJ, Bronin LE (eds) Estuaries and nutrients. Humana Press, Inc, pp 111-138

12. Palumbo AV, Ferguson RL (1978) Distribution of suspended bacteria in the Newport River estuary, North Carolina. Estuar Coast Mar Sci 7:521-529

13. Rublee PA (1982) Seasonal distribution of bacteria in salt marsh sediments of North Carolina. Estuarine, Coastal and Shelf Science 15:67-74

14. Schmidt GW (1970) Number of bacteria and algae and their interrelations in some Amazonian waters. Amazonia 2:393-400

15. Strickland JDH, Parsons TR (1972) A practical handbook of sea water analysis. J Fish Res Board Can 167 
16. Sverdrup HU, Johnson MW, Fleming RH (1942) The oceans, their physics, chemistry and general biology. Prentice-Hall, Englewood Cliffs, New Jersey

17. Thornton I (1965) Nutrient content of rainwater in The Gambia. Nature (No. 4975) 205:1025

18. Visser SA (1973) Pre-impoundment features of the Kainji area and their possible influence on the ecology of the newly formed lake. In: Ackermann WC et al. (eds) Man-made lakes: their problems and environmental effects. Geophysical Monograph 17, American Geophysical Union, Washington, DC

19. Wetzel RG (1975) Limnology. WB Saunders, Philadelphia

20. Williams PJ leB (1981) Incorporation of microheterotrophic processes into the classical paradigm of the planktonic food web. Kiel Meeresfor Sonderh 5:1-28

21. Winer BJ (1976) Statistical principles in experimental design. McGraw-Hill, New York

22. Wright RT (1978) Measurement and significance of specific activity in the heterotrophic bacteria of natural waters. Appl Environ Microbiol 36:297-305

23. Wright RT, Burnison BK (1979) Heterotrophic activity measured with radiolabelled organic substrates. In: Costerton JW, Colwell RR (eds) Native aquatic bacteria. American Society for Testing Materials, Philadelphia, pp 140-155

24. Wright RT, Coffin RB (1983) Planktonic bacteria in estuaries and coastal waters of northern Massachusetts: spatial and temporal distribution. Mar Ecol Progr Ser 11:205-216

25. Wright RT, Coffin RB (1984) Measuring microzooplankton grazing on planktonic marine bacteria by its impact on bacterial production. Microb Ecol 10:137-149 